\title{
Correction to: Composite Scaffolds of Mineralized Natural Extracellular Matrix on True Bone Ceramic Induce Bone Regeneration Through Smad1/5/8 and ERK1/2 Pathways by Sun T, Yao S, Liu M, Yang Y, Ji Y, Cui W, Qu Y, Guo X. Tissue Eng Part A 2018;24(5-6):502-515. DOI: 10.1089/ten.tea.2017.0179
}

\begin{abstract}
TN The March 2018 issue of Tissue Engineering, Part A (vol. 24, no. 5-6, pages 502-515), in the article entitled Composite Scaffolds of Mineralized Natural Extracellular Matrix on True Bone Ceramic Induce Bone Regeneration Through Smad1/5/8 and ERK1/2 Pathways by Tingfang Sun et al., the authors have discovered errors in the text and legend for Figure 9. The errors are listed as following. The corrections are shown in bold.
\end{abstract}

Page 503, section "Preparation of mineralized SIS and deposition on TBC", on the 6th line below the section head, the expression " $10-20 \mathrm{~mm}$ " should be changed to "10-20 $\boldsymbol{\mu m}$."

Page 505, section "Western blot analysis", on the 8th line below the section head, the expression "for 14 days" should be changed to "for 7 days."

Page 505, section "Western blot analysis, on the $17^{\text {th }}$ and $18^{\text {th }}$ lines below the section head, the expression "treatment for 7 and 14 days" should be changed to "treatment for 7 days."

Page 507, section "Results", on the $3^{\text {rd }}$ line from the top of the left column, the sentence, "The amount of carbon increased from $0.54 \%$ in pure TBC to $9.2 \%$ in SIS/TBC, owing to the deposition of SIS on TBC." This should be changed to "The amount of carbon increased from $\mathbf{3 1 . 1 7 \%}$ in pure TBC to $\mathbf{6 9 . 5 7 \%}$ in SIS/TBC, owing to the deposition of SIS on TBC." The data previously presented in text was not in accordance with that presented in Table 2.

Page 511, in the legend for Figure 9, in the sentence, "The expression levels of these molecules in cells cultured on mSIS/ TBC and in the cells treated with the specific inhibitor for the corresponding pathway were examined at 14 days," should be changed to "The expression levels of these molecules in cells cultured on mSIS/TBC and in the cells treated with the specific inhibitor for the corresponding pathway were examined at $\mathbf{7}$ days."

Page 513, section "Conclusions", on the $2^{\text {nd }}$ and $3^{\text {rd }}$ lines above the section head, the expression "mSIS/TBC" should be changed to "mdECM/TBC."

The authors sincerely regret these errors. 